\title{
PENGARUH APLIKASI PUPUK SULFUR DAN JUMLAH SIUNG TERHADAP PERTUMBUHAN DAN PRODUKSI BAWANG PUTIH (Allium sativum L.) SERTA RESIDU SULFUR DI INCEPTISOL KARANGPLOSO
}

\section{Effect of Sulphur Fertilizer and Number of Cloves on Growth and Yield of Garlic (Allium sativum L.) and Sulphur Residue in Inceptisol of Karangploso}

\author{
Balqis Noor Hanifah ${ }^{1 *}$, Retno Suntari ${ }^{1}$, Baswarsiati ${ }^{2}$ \\ ${ }^{1}$ Jurusan Ilmu Tanah, Fakultas Pertanian, Universitas Brawijaya, Jl. Veteran No 1 Malang 65145 \\ ${ }^{2}$ Balai Pengkajian Teknologi Pertanian Jawa Timur \\ *Penulis korespondensi: balqis23hanifah@gmail.com
}

\begin{abstract}
Garlic (Allium sativum L.) is a plant that is often used by Indonesian people in various ways. One of the reasons for the low productivity of garlic in Indonesia is the insufficient use of superior varieties and low $\mathrm{S}$ elements in the soil. Furthermore, the use of the number of cloves planted per planting hole will determine the number of populations so that it will affect the growth and production of garlic. The aim of this study was to analyze the effect of $\mathrm{S}$ fertilizer and the number of cloves on the growth and production of garlic (Allium sativum L.) and also analysis $\mathrm{S}$ residue from $\mathrm{S}$ fertilizer and number of cloves. This study used a randomized block design with nine treatment combinations, three levels of sulfur fertilizer doses $\left(0 \mathrm{~kg} \mathrm{~S} \mathrm{ha}^{-1}, 140 \mathrm{~kg} \mathrm{~S} \mathrm{ha}^{-1}\right.$ and $\left.200 \mathrm{~kg} \mathrm{Sha}^{-1}\right)$ and the number of cloves ( 1 clove, 2 cloves and 3 cloves). The results showed that the application of sulfur fertilizer and the number of cloves had no significant effect on growth parameters (plant height and number of leaves) in garlic plants. However, it significantly increased the diameter of bulbs, fresh bulbs weight and dry bulbs weight respectively by $13.39 \%, 140.72 \%$ and $93.64 \%$ to $24.29 \mathrm{~mm}, 5.97 \mathrm{~g} \mathrm{plant}^{-1}$ and $4.57 \mathrm{~g} \mathrm{plant}^{-1}$ in the treatment of one number of clove and $140 \mathrm{~kg}$ of S ha- $\mathrm{S}^{-1}$ compared to the treatment of one clove and without $\mathrm{S}$. As well as significant effect on $\mathrm{SO}_{4}{ }^{2-}$ residues and total $\mathrm{S}$ with the highest yield respectively $299.3 \mathrm{ppm}$ and $910 \mathrm{ppm}$ and the lowest yield was obtained in the treatment without $S$ fertilizer.
\end{abstract}

Keywords: garlic Kayu varieties, growth, production, total $S$ and $S$ residues

\section{Pendahuluan}

Bawang putih (Allium sativum L.) merupakan tanaman umbi-umbian yang menjadi salah satu komoditas terpenting dan telah lama digunakan oleh masyarakat Indonesia sebagai bahan pengolahan makanan dan obat-obatan (Amagase et al., 2006). Produksi bawang putih di Indonesia dan di daerah Jawa Timur pada tahun 2016 mengalami penurunan dari 21.151 ton menjadi 19.510 ton pada tahun 2017 . Demikian pula produksi bawang putih di Jawa
Timur mengalami penurunan dari 777 ton menjadi 653 ton. Produktivitas bawang putih varietas Lumbu Kuning dan Lumbu Hijau di Jawa Timur tahun 2017 rata-rata 6,7 $\mathrm{t} \mathrm{ha}^{-1}$ (Badan Pusat Statistik, 2018). Menurunnya produksi bawang putih antara lain dapat disebabkan oleh harga bawang putih impor lebih murah serta ukuran umbi yang lebih besar dari pada bawang putih lokal. Menurut Prastuti et al. (2011) rendahnya produktivitas bawang putih juga disebabkan oleh penerapan kultur teknis budidaya yang belum sesuai dengan SOP 


\section{Jurnal Tanah dan Sumberdaya Lahan Vol 8 No 1: 43-50, 2021 \\ e-ISSN:2549-9793, doi: 10.21776/ub.jts1.2021.008.1.6}

(Standar Operasional Prosedure). Selain itu, penggunaan benih dengan kualitas unggul masih belum memadai sehingga produktivitas bawang putih rendah.

Salah satu sentra pertanaman bawang putih di Jawa Timur terletak di daerah Karangploso yang memiliki jenis tanah Inceptisol dengan unsur $\mathrm{S}$ dan $\mathrm{P}$ tersedia rendah. Hal tersebut dapat diatasi dengan intensifikasi lahan. Pemupukan dengan pupuk S dapat meningkatkan ketersediaan unsur $\mathrm{S}$ di dalam tanah, pertumbuhan, serta kualitas bawang putih. Selain itu setelah unsur hara $\mathrm{S}$ diserap oleh tanaman masih meninggalkan residu pada tanah ketika ditanam pada musim hujan. Hal ini dapat terjadi antara lain disebabkan terjadinya pencucian $\mathrm{SO}_{4}{ }^{-}$dalam tanah (Jaggi dan Raina, 2008).

Varietas Kayu adalah varietas bawang putih yang berumur genjah dan tahan terhadap organisme pengganggu tanaman (Balai Pengkajian Teknologi Pertanian Jawa Timur, 2018). Selain faktor pemupukan dan penggunaan varietas unggul, jumlah bibit yang ditanam per lubang tanam juga akan mempengaruhi pertumbuhan dan produksi tanaman bawang putih. Jumlah bibit per lubang tanam dapat mempengaruhi tingkat populasi tanaman per satuan luas, sedangkan tingkat populasi sangat mempengaruhi pertumbuhan dan produksi tanaman pada suatu areal penanaman (Sufyati et al., 2006). Belum ada informasi yang jelas berapa jumlah umbi bibit per lubang tanam yang baik guna untuk meningkatkan pertumbuhan dan produksi. Namun beberapa peneliti telah melaporkan pengaruh aplikasi pupuk pada produksi tanaman bawang putih dan terhadap residu S (Jaggi dan Raina, 2008; Putra, 2013; Shiferaw et al., 2015).

Tujuan penelitian ini adalah untuk mengetahui pengaruh pupuk $S$ dan jumlah siung terhadap pertumbuhan dan produksi tanaman bawang putih serta residu $S$ tanah Inceptisol Karangploso.

\section{Bahan dan Metode}

Penelitian dilaksanakan di kebun percobaan Balai Pengkajian Teknologi Pertanian Jawa Timur yang berlokasi di Jl. Raya Karangploso Km. 4 pada bulan November 2019 sampai Juni 2020. Analisis tanah dasar dilakukan di
Laboratorim Kimia Jurusan Tanah, Fakultas Pertanian, Universitas Brawijaya dan Laboratorium Kimia Balai Pengkajian Teknologi Pertanian Jawa Timur. Penelitian ini menggunakan rancangan acak kelompok dengan sembilan kombinasi perlakuan, 3 taraf dosis pupuk sulfur $\left(0 \mathrm{~kg} \mathrm{~S} \mathrm{ha} a^{-1}, 140 \mathrm{~kg} \mathrm{~S} \mathrm{ha}^{-1}\right.$ dan $200 \mathrm{~kg} \mathrm{~S} \mathrm{ha}^{-1}$ ). dan jumlah siung (1 siung, 2 siung, dan 3 siung).

\section{Pengambilan sampel tanah dan persiapan benih}

Pengambilan sampel tanah dilakukan pada saat sebelum penanaman, sampel tanah yang diambil merupakan tanah komposit dari lahan penelitian dengan pola zig-zag. Kemudian dilakukan persiapan benih yang diawali dengan penyortiran benih guna untuk memisahkan benih yang layak tanam dan benih yang rusak, pengaplikasian pestisida yang dilakukan dengan cara merendam benih ke dalam larutan insektisida sebelum dimasukkan ke dalam gudang penyimpanan dan dilakukan penyemprotan setiap dua minggu sekali setelah masuk gudang penyimpanan, kemudian pematahan dormansi dengan cara memindahkan benih dari gudang penyimpanan ke dalam coldstorage dengan suhu $10^{\circ} \mathrm{C}$ dan merumih yaitu kegiatan pemisahan benih dari siungnya, dalam proses merumih diperlukan ketelitian agar benih tidak rusak.

\section{Persiapan Lahan}

Persiapan lahan diawali dengan pengolahan tanah yang dilakukan dengan cara membalikkan tanah menggunakan cangkul. Selanjutnya dilakukan pembuatan bedengan berukuran $1 \mathrm{mx}$ $1 \mathrm{~m}$ dan parit antar bedengan berukuran $30 \mathrm{~cm}$. Kemudian dilakukan solarisasi tanah yang bertujuan agar kondisi tanah menjadi sehat. Solarisasi tanah dilakukan dengan cara menyiram tanah dengan air sampai lembab sedalam $15 \mathrm{~cm}$ dan menutup bedengan dengan plastik bening selama 2-3 minggu. Kemudian dilakukan pemasangan mulsa menggunakan jenis mulsa MPHP (Mulsa Plastik Hitam Perak), dengan meletakkan mulsa di atas bedengan kemudian direkatkan oleh potongan kayu.

\section{Penanaman dan pemupukan}

Penanaman dilakukan dengan membenamkan bagian pangkal benih bawang putih sekitar 3/4 


\section{Jurnal Tanah dan Sumberdaya Lahan Vol 8 No 1: 43-50, 2021 \\ e-ISSN:2549-9793, doi: 10.21776/ub.jts1.2021.008.1.6}

bagian siung ke dalam tanah dan $1 / 4$ bagian berada di atas permukaan tanah kemudian dibumbun dengan tanah. Benih bawang putih ditanam pada jarak tanam 8 x $10 \mathrm{~cm}$. Pupuk dasar yang digunakan berupa pupuk kandang kambing dengan dosis $20 \mathrm{t} \mathrm{ha}^{-1}$ dan pupuk SP36 sebesar 333,33 $\mathrm{kg} \mathrm{ha} \mathrm{ha}^{-1}$ yang diaplikasikan pada saat sebelum tanam. Pupuk anorganik ZA, pupuk $\mathrm{KCl}$ diaplikasikan sebanyak 4 kali selama musim tanam yaitu pada saat 15, 30, 45 dan 60 HST. Sedangkan pupuk $\mathrm{KNO}_{3}$ merah $(14 \%$ $\left.\mathrm{K}_{2} \mathrm{O}\right)$ dan $\mathrm{KNO}_{3}$ putih $\left(45 \% \mathrm{~K}_{2} \mathrm{O}\right)$ masingmasing $1 / 4$ dan $3 / 4$ bagian. Dolomit sebanyak 300 $\mathrm{kg} \mathrm{ha}^{-1}$ diaplikasikan sebelum masa tanam berdasarkan rekomendasi BPTP Jatim (2018).

\section{Pemeliharaan dan pengamatan tanaman}

Penyiraman dilakukan dua hari sekali dengan mengalirkan air dari sumbernya ke parit pada lahan budidaya. Penyiangan gulma dilakukan seminggu sekali dengan mencabut gulma di sekitar tanaman bawang putih. Pengamatan tanaman bawang putih dilakukan pada saat 30 dan 60 HST. Parameter yang diamati adalyah tinggi tanaman dan jumlah daun.

\section{Pemanenan dan pengamatan hasil panen}

Tahap pemanenan dilakukan ketika bawang putih sudah berumur 3 bulan atau sekitar 90-95 HST. Setelah itu bawang putih yang sudah dipanen dibersihkan dari sisa-sisa tanah, daundaun yang kering dan dibuang akarnya. Kemudian dilakukan pengamatan terhadap diameter umbi serta berat segar umbi. Umbi bawang putih dikering anginkan selama 2 minggu untuk mendapatkan berat kering umbi.

\section{Analisis laboratorium dan analisa data}

Tahap analisis laboratorium pada penelitian ini yaitu analisis dasar tanah yang dilakukan pada sampel tanah sebelum dilakukan penanaman dan analisis residu $\mathrm{SO}_{4}{ }^{2-}$ dan $\mathrm{S}$ total setelah kegiatan pemanenan. Hasil analisis dasar tanah Inceptisol yang dilaksanakan sebelum penelitian disajikan pada Tabel 1. Analisis data yang dilakukan setelah penelitian menggunakan analisis ragam anova dengan uji taraf 5\% untuk mengetahui pengaruh dari perlakuan terhadap parameter pengamatan. Apabila perlakuan berpengaruh nyata terhadap parameter pengamatan maka dilakukan uji DMRT (Duncan
Multiple Range Test) untuk mengetahui perbedaan antar perlakuan.

Tabel 1. Karakteristik tanah yang digunakan dalam penelitian.

\begin{tabular}{|c|c|c|}
\hline Parameter & $\begin{array}{c}\text { Hasil } \\
\text { Analisis } \\
(* *)\end{array}$ & Kriteria* \\
\hline $\mathrm{pH} \mathrm{H} \mathrm{H}_{2} \mathrm{O}$ & 6,2 & Agak masam \\
\hline C-Organik (\%) & 2,78 & Sedang \\
\hline Nitrogen Total $(\%)$ & 0,39 & Sedang \\
\hline Rasio C/N & 2,96 & $\begin{array}{l}\text { Sangat } \\
\text { rendah }\end{array}$ \\
\hline $\begin{array}{l}\mathrm{P}_{2} \mathrm{O}_{5} \text { tersedia } \\
(\mathrm{ppm})\end{array}$ & 0,13 & $\begin{array}{l}\text { Sangat } \\
\text { rendah }\end{array}$ \\
\hline $\mathrm{SO}_{4}(\mathrm{ppm})$ & 24 & $\begin{array}{l}\text { Sangat } \\
\text { rendah }\end{array}$ \\
\hline S-total $(\%)$ & 0,03 & \\
\hline \multicolumn{3}{|l|}{$\begin{array}{l}\text { Kation dapat } \\
\text { ditukar: }\end{array}$} \\
\hline $\mathrm{K}\left(\right.$ me $\left.100 \mathrm{~g}^{-1}\right)$ & 1,46 & Sangat tinggi \\
\hline $\mathrm{Ca}\left(\right.$ me $\left.\left.100 \mathrm{~g}^{-1}\right)\right)$ & 2,08 & Rendah \\
\hline $\operatorname{Mg}\left(\right.$ me $\left.100 \mathrm{~g}^{-1}\right)$ & 7,60 & Tinggi \\
\hline $\mathrm{Na}\left(\right.$ me $\left.100 \mathrm{~g}^{-1}\right)$ & 0,58 & Sedang \\
\hline $\mathrm{KTK}\left(\mathrm{cmol} 100 \mathrm{~g}^{-1}\right)$ & 22,91 & Sedang \\
\hline $\mathrm{KB}(\%)$ & 51,15 & Sedang \\
\hline Tekstur & & Liat berdebu \\
\hline Pasir (\%) & 26 & \\
\hline Debu $(\%)$ & 28 & \\
\hline Liat $(\%)$ & 46 & \\
\hline
\end{tabular}

Keterangan: $(*)$ Berdasarkan Balai Penelitian Tanah (2009). (**)Analisa di Laboratorium Tanah BPTP Jatim.

\section{Hasil dan Pembahasan}

\section{Tinggi tanaman dan jumlah daun}

Pengamatan parameter tinggi tanaman dan jumlah daun dengan analisis ragam menunjukkan bahwa perlakuan pupuk sulfur dan jumlah siung tidak berpengaruh nyata terhadap parameter tinggi tanaman dan jumlah daun bawang putih pada 30 HST dan 60 HST (Tabel 2).

\section{Diameter umbi}

Hasil analisis ragam menunjukkan bahwa perlakuan pupuk sulfur dan jumlah siung berpengaruh nyata terhadap parameter diameter umbi bawang putih. Rata-rata diameter umbi bawang putih disajikan pada Tabel 3 . 


\section{Jurnal Tanah dan Sumberdaya Lahan Vol 8 No 1: 43-50, 2021 \\ e-ISSN:2549-9793, doi: 10.21776/ub.jts1.2021.008.1.6}

Tabel 2. Pengaruh aplikasi pupuk S dan jumlah siung terhadap rata-rata tinggi tanaman dan jumlah daun bawang putih.

\begin{tabular}{ccccc}
\hline Perlakuan & $\begin{array}{c}\text { E Tinggi } \\
\text { Tanaman } \\
(\mathbf{c m})\end{array}$ & \multicolumn{2}{c}{$\begin{array}{c}\text { Jumlah } \\
\text { Daun } \\
\text { (helai) }\end{array}$} \\
\cline { 2 - 5 } & $\mathbf{3 0}$ & $\mathbf{6 0}$ & $\mathbf{3 0}$ & $\mathbf{6 0}$ \\
& HST & HST & HST & HST \\
\hline S1P1 & 26,91 & 30,03 & 4 & 5 \\
S1P2 & 25,64 & 27,07 & 4 & 4 \\
S2P0 & 27,28 & 31,86 & 4 & 5 \\
S2P1 & 25,74 & 29,34 & 4 & 5 \\
S2P2 & 28,41 & 32,82 & 4 & 5 \\
S3P0 & 26,18 & 31,56 & 4 & 4 \\
S3P1 & 26,18 & 31,41 & 4 & 5 \\
S3P2 & 23,67 & 25,67 & 4 & 4 \\
S1P1 & 26,91 & 30,03 & 4 & 5 \\
\hline
\end{tabular}

Keterangan: $\mathrm{S} 1=$ jumlah siung 1 ; $\mathrm{S} 2=$ jumlah siung 2; $\mathrm{S} 3=$ jumlah siung 3; $\mathrm{P} 0=0 \mathrm{~kg} \mathrm{~S} \mathrm{ha}{ }^{-1} \mathrm{~S} ; \mathrm{P} 1=140$ $\mathrm{kg} \mathrm{S} \mathrm{ha}{ }^{-1} \mathrm{~S} ; \mathrm{P} 2=200 \mathrm{~kg} \mathrm{~S} \mathrm{ha-1}$, HST = hari setelah tanam.

Tabel 3. Pengaruh aplikasi pupuk S dan jumlah siung terhadap rata-rata diameter umbi bawang putih.

\begin{tabular}{ccc}
\hline Perlakuan & $\begin{array}{c}\text { Diameter Umbi } \\
(\mathbf{m m})\end{array}$ & $\mathbf{( + \% )}$ \\
\hline S1P0 & $21,42 \mathrm{~b}$ & \\
S1P1 & $24,29 \mathrm{c}$ & 13,39 \\
S1P2 & $21,04 \mathrm{ab}$ & -1.77 \\
S2P0 & $20,39 \mathrm{ab}$ & $-4,8$ \\
S2P1 & $20,49 \mathrm{ab}$ & $-4,34$ \\
S2P2 & $20,03 \mathrm{ab}$ & $-6,49$ \\
S3P0 & $20,08 \mathrm{ab}$ & $-6,25$ \\
S3P1 & $20,86 \mathrm{ab}$ & $-2,61$ \\
S3P2 & $19,04 \mathrm{a}$ & $-11,11$ \\
\hline
\end{tabular}

Keterangan: $\mathrm{S} 1=$ jumlah siung $1 ; \mathrm{S} 2=$ jumlah siung 2; $\mathrm{S} 3=$ jumlah siung $3 ; \mathrm{P} 0=0 \mathrm{~kg} \mathrm{~S}^{-1} \mathrm{~S} ; \mathrm{P} 1=140$ $\mathrm{kg} \mathrm{S} \mathrm{ha-1} \mathrm{S;} \mathrm{P2}=200 \mathrm{~kg} \mathrm{~S} \mathrm{ha}^{-1} ;(+\%)$ peningkatan.

Aplikasi pupuk sulfur sebesar $140 \mathrm{~kg} \mathrm{ha-1}$ dengan satu siung bawang putih dapat meningkatkan diameter umbi bawang putih sebesar 13,39\% dibandingkan tanpa perlakuan sulfur (P0). Hal ini didukung dari penelitian Babaleshwar et al. (2017) yang menunjukkan bahwa dengan mengaplikasikan pupuk sulfur 60 $\mathrm{kg} \mathrm{ha}^{-1}$ dapat meningkatkan diameter umbi sebesar 9,70\% dengan hasil tertinggi sebesar
36,27 $\mathrm{mm}$ dan perlakuan terendah didapat dengan perlakuan sulfur $15 \mathrm{~kg} \mathrm{ha}^{-1}$ yaitu sebesar 33,06 $\mathrm{mm}$. Penelitian ini menghasilkan diameter umbi yang lebih rendah daripada peneliti tersebut di atas. Hal ini karena penggunaan umbi bawang putih lokal aksesi Kayu yang memiliki ukuran umbi lebih kecil dibanding varietas lainnya namun berumur genjah dan tahan OPT. Lebih rendahnya rata-rata diameter umbi bawang putih dengan bertambahnya aplikasi pupuk $\mathrm{S}$ dan jumlah siung umbi diduga karena terjadinya penurunan nilai $\mathrm{pH}$ (Tabel 7) dan kompetisi unsur hara dalam tanah (Li et al., 2011; Zaman et al., 2011; Putra, 2013).

\section{Berat umbi segar bawang putih}

Pengamatan parameter berat umbi segar bawang putih pada saat panen memberikan hasil yang lebih tinggi dibandingkan dengan hasil beberapa peneliti (Putra, 2013; Hore et al., 2014; Karo, 2017). Hasil analisis ragam menunjukkan bahwa perlakuan pupuk sulfur dan jumlah siung berpengaruh nyata dan terdapat perbedaan nyata antar perlakuan terhadap parameter berat umbi segar bawang putih (Tabel 4). Perlakuan

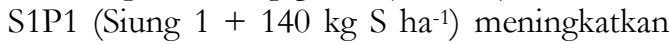
$140,72 \%$ berat umbi segar bawang putih dibandingkan perlakuan kontrol (S1P0).

Tabel 4. Pengaruh aplikasi pupuk S dan jumlah siung terhadap rata-rata berat segar umbi bawang putih.

\begin{tabular}{ccc}
\hline Perlakuan & $\begin{array}{c}\text { Berat Umbi Segar } \\
\text { (g tanaman }\end{array}$ & $\mathbf{( + \% )}$ \\
\hline S1P0 & $2,48 \mathrm{a}$ & \\
S1P1 & $5,97 \mathrm{c}$ & 140,72 \\
S1P2 & $4,23 \mathrm{ab}$ & 70,56 \\
S2P0 & $3,83 \mathrm{ab}$ & 54,43 \\
S2P1 & $3,57 \mathrm{ab}$ & 43,95 \\
S2P2 & $4,60 \mathrm{~b}$ & 85,48 \\
S3P0 & $3,62 \mathrm{ab}$ & 45,46 \\
S3P1 & $3,72 \mathrm{ab}$ & 50,00 \\
S3P2 & $2,46 \mathrm{a}$ & 4,83 \\
\hline
\end{tabular}

Keterangan: $\mathrm{S} 1=$ jumlah siung $1 ; \mathrm{S} 2=$ jumlah siung 2; $\mathrm{S} 3=$ jumlah siung $3 ; \mathrm{P} 0=0 \mathrm{~kg} \mathrm{Sha}^{-1} \mathrm{~S} ; \mathrm{P} 1=140$ $\mathrm{kg} \mathrm{S} \mathrm{ha}{ }^{-1} \mathrm{~S} ; \mathrm{P} 2=200 \mathrm{~kg} \mathrm{~S} \mathrm{ha}^{-1} ;(+\%)$ peningkatan.

Peningkatan berat umbi segar ini diduga dipengaruhi oleh aplikasi pupuk ZA yang mengandung unsur S 24\% dan unsur N 21\% 


\section{Jurnal Tanah dan Sumberdaya Lahan Vol 8 No 1: 43-50, 2021 \\ e-ISSN:2549-9793, doi: 10.21776/ub.jts1.2021.008.1.6}

yang diperlukan dalam proses pertumbuhan dan mampu meningkatkan penyerapan unsur hara esensial pada tanaman sehingga dapat berperan dalam pembentukan umbi. Hal ini didukung oleh pernyataan Putra (2013) yang menyatakan bahwa dengan aplikasi pupuk ZA sebesar $125 \mathrm{~kg}$ ha $^{-1}$ menunjukkan hasil berbeda nyata dari perlakuan kontrol. Selanjutnya ditambahkan bahwa aplikasi pupuk ZA sebesar $250 \mathrm{~kg} \mathrm{ha-1}$ mampu meningkatkan 15,03\% berat umbi segar bawang putih dibandingkan perlakuan kontrol.

\section{Berat umbi kering bawang putih}

Produktivitas tanaman dipengaruhi oleh pengelolaan lahan diantaranya aplikasi pupuk yang seimbang. Hasil analisis ragam menunjukkan bahwa perlakuan pupuk sulfur dan jumlah siung berpengaruh nyata terhadap berat umbi kering pada bawang putih. Rata-rata berat umbi kering bawang putih disajikan pada Tabel 5.

Tabel 5. Pengaruh aplikasi pupuk S dan jumlah siung terhadap berat kering tanaman bawang putih.

\begin{tabular}{ccc}
\hline Perlakuan & $\begin{array}{c}\text { Berat Umbi Kering } \\
\left.\text { (g tanaman }^{-1}\right)\end{array}$ & $\mathbf{( + \% )}$ \\
\hline S1P0 & $2,36 \mathrm{a}$ & \\
S1P1 & $4,57 \mathrm{~b}$ & 93,64 \\
S1P2 & $2,73 \mathrm{a}$ & 15,67 \\
S2P0 & $2,72 \mathrm{a}$ & 15,25 \\
S2P1 & $2,40 \mathrm{a}$ & 1,69 \\
S2P2 & $3,05 \mathrm{a}$ & 29,23 \\
S3P0 & $2,47 \mathrm{a}$ & 4,66 \\
S3P1 & $2,73 \mathrm{a}$ & 15,67 \\
S3P2 & $1,69 \mathrm{a}$ & $-28,38$ \\
\hline
\end{tabular}

Keterangan: $\mathrm{S} 1=$ jumlah siung $1 ; \mathrm{S} 2=$ jumlah siung 2; S3 = jumlah siung 3; P0 $=0 \mathrm{~kg} \mathrm{~S} \mathrm{ha-1} \mathrm{S} ; \mathrm{P} 1=140$ kg S ha ${ }^{-1} \mathrm{~S} ; \mathrm{P} 2=200 \mathrm{~kg} \mathrm{~S} \mathrm{ha}^{-1} ;(+\%)$ peningkatan.

Berat umbi kering bawang putih tertinggi diperoleh dari perlakuan S1P1 (jumlah siung 1+ $140 \mathrm{~kg} \mathrm{ha}^{-1}$ ) sesuai dengan hasil berat umbi segar (Tabel 4) dan berbeda nyata dengan semua perlakuan yang diteliti. Perlakuan S1P1 (jumlah siung $1+140 \mathrm{~kg} \mathrm{ha}^{-1}$ ) pada tanaman bawang putih mampu meningkatkan berat umbi kering bawang putih sebesar 93,64\%. Menurut Fatmawati et al. (2018) perlakuan sumber S dapat meningkatkan panjang daun, berat segar umbi per rumpun, berat umbi kering simpan per rumpun, berat segar umbi per petak dan berat umbi kering simpan per petak. Hal tersebut diduga karena unsur $\mathrm{S}$ merupakan bagian penting dari ferodoksin yaitu suatu kompleks Fe dan $S$ yang terdapat dalam kloroplas yang digunakan dalam katabolisme karbohidrat untuk membentuk fotosintat yang optimal. Selanjutnya fotosintat akan ditranslokasikan ke seluruh bagian tanaman bawang putih dan akan disimpan dalam bentuk umbi. Rendahnya berat umbi kering bawang putih yang dihasilkan dalam penelitian ini diduga disebabkan oleh ukuran umbi lokal varietas Kayu yang ditanam tidak besar. Hal ini sesuai dengan pernyataan Sufyati et al. (2006) yang menyatakan bahwa ukuran fisik umbi bibit yang berukuran besar akan menghasilkan pertumbuhan dan produksi terbaik karena cenderung mempunyai penampang akar yang lebih luas sehingga jumlah akar yang tumbuh akan lebih banyak.

\section{Residu $\mathrm{SO}_{4}^{2-}$ dan $\mathrm{S}$ total dalam tanah}

Residu pupuk S pada penelitian ini didapatkan dari hasil analisis $\mathrm{S}$ total dan $\mathrm{SO}_{4}{ }^{2-}$ dalam tanah setelah panen tanaman bawang putih. Perlakuan pupuk sulfur dan jumlah siung berdasarkan hasil analisis ragam berpengaruh nyata terhadap parameter $\mathrm{SO}_{4}^{2-}$ dan $\mathrm{S}$ total dalam tanah (Tabel 6). Hasil analisis ragam terhadap residu $\mathrm{SO}_{4}{ }^{2-}$ bawang putih menunjukkan bahwa perlakuan S2P1 (Siung 2 + $140 \mathrm{~kg} \mathrm{~S} \mathrm{ha}^{-1}$ ) menghasilkan residu $\mathrm{SO}_{4}{ }^{2-}$ tertinggi (299,3 $\left.\mathrm{ppm}\right)$.

Berbeda dengan hasil residu $\mathrm{S}$ total yang menunjukkan perlakuan S1P2 (Siung $1+200 \mathrm{~kg}$ $\mathrm{S} \mathrm{ha}^{-1}$ ) menghasilkan residu tertinggi (910 ppm). Sedangkan residu $\mathrm{S}$ total terrendah diperoleh pada perlakuan tanpa pupuk sulfur yaitu S3P0 (Siung 3 + $0 \mathrm{~kg} \mathrm{~S} \mathrm{ha}{ }^{-1}$ ) yaitu sebesar 450 ppm. Hal ini sejalan dengan pernyataan Aisyah et al. (2015) bahwa aplikasi pupuk sulfur sebesar 250 $\mathrm{kg} \mathrm{ha-1}$ menggunakan pupuk ZA dapat meningkatkan 38,58\% residu $\mathrm{SO}_{4}{ }^{2-}$ dan merupakan hasil tertinggi $(26,58 \mathrm{ppm})$ serta berbeda sangat nyata dari perlakuan kontrol yang memiliki hasil terendah (19,18 ppm).

$\mathrm{Hal}$ ini disebabkan pupuk $\mathrm{ZA}\left[\left(\mathrm{NH}_{4}\right)_{2} \mathrm{SO}_{4}\right]$ memiliki kandungan sulfur dalam bentuk sulfat $\left(\mathrm{SO}_{4}{ }^{2-}\right)$ merupakan pupuk fast release yang langsung dapat diserap oleh tanaman bawang putih. Sulfur yang diaplikasikan ke dalam tanah akan diubah menjadi $\mathrm{H}_{2} \mathrm{SO}_{4}$ oleh mikroorganisme dan $\mathrm{H}_{2} \mathrm{SO}_{4}$ yang terbentuk 


\section{Jurnal Tanah dan Sumberdaya Lahan Vol 8 No 1: 43-50, 2021 \\ e-ISSN:2549-9793, doi: 10.21776/ub.jts1.2021.008.1.6}

akan bereaksi dengan Dolomit $\mathrm{CaMg}\left(\mathrm{CO}_{3}\right)_{2}$ yang melepaskan $\mathrm{Ca}^{++}$selanjutnya akan menambah ketersediaan sulfat dan fosfat (Mashtura et al., 2013). Residu S total tinggi pada perlakuan dosis sulfur $200 \mathrm{~kg} \mathrm{ha}^{-1}$ kemungkinan dapat mengakibatkan unsur sulfur yang berlebih setelah digunakan oleh mikroorganisme dalam tanah. Mikroorganisme juga membutuhkan unsur S untuk metabolisme dan memperbanyak populasinya (Havlin et al., 1999). Unsur sulfur yang ditambahkan ke tanah juga berupa aplikasi pupuk kandang kambing sebagai pupuk dasar bertujuan untuk meningkatkan sifat fisika, kimia dan biologi tanah. Menurut Sunaryo et al. (2018) pupuk kandang kambing memiliki kandungan $\mathrm{S}$ total sebesar 16,09 ppm, $\mathrm{N}$ total $0,11 \%, \mathrm{P}_{2} \mathrm{O}_{5}$ $0,14 \%, \mathrm{~K}_{2} \mathrm{O} 0,16 \%$, Ca 0,09\%, Mg total 0,06\%, Fe total 29,46 ppm dan Mn total 13,45 ppm. Oleh karena itu pupuk kandang kambing dapat menambah unsur hara esensial makro dan mikro dalam tanah. Selain dapat memperbaiki sifat kimia pada tanah, pupuk kandang kambing juga mampu memperbaiki sifat fisika pada tanah dengan memperbaiki struktur tanah, kapasitas tanah menahan air dan memperbaiki aerasi di tanah.

Tabel 6. Pengaruh aplikasi pupuk $\mathrm{S}$ dan jumlah siung terhadap residu $\mathrm{SO}_{4^{2-}}$ dan $\mathrm{S}$ total.

\begin{tabular}{cccc}
\hline Perlakuan & ${\text { Residu } \mathbf{S O}_{4}{ }^{2-} \mathbf{( p p m )}}$ & Kriteria & Residu S total $\mathbf{( p p m )}$ \\
\hline S1P0 & $188,7 \mathrm{a}$ & Sedang & $500 \mathrm{ab}$ \\
S1P1 & $260,8 \mathrm{bc}$ & Tinggi & $630 \mathrm{bc}$ \\
S1P2 & $241,7 \mathrm{abc}$ & Sedang & $910 \mathrm{~d}$ \\
S2P0 & $250,0 \mathrm{abc}$ & Tinggi & $460 \mathrm{ab}$ \\
S2P1 & $299,3 \mathrm{c}$ & Tinggi & $610 \mathrm{abc}$ \\
S2P2 & $229,3 \mathrm{ab}$ & Sedang & $850 \mathrm{~cd}$ \\
S3P0 & $218,9 \mathrm{ab}$ & Sedang & $450 \mathrm{a}$ \\
S3P1 & $267,1 \mathrm{bc}$ & Tinggi & $590 \mathrm{ab}$ \\
S3P2 & $2477 \mathrm{abc}$ & Sedang & $830 \mathrm{~cd}$ \\
\hline
\end{tabular}

Keterangan: $\mathrm{S} 1=$ jumlah siung $1 ; \mathrm{S} 2=$ jumlah siung 2; $\mathrm{S} 3=$ jumlah siung $3 ; \mathrm{P} 0=0 \mathrm{~kg} \mathrm{~S} \mathrm{ha}^{-1} \mathrm{~S} ; \mathrm{P} 1=140 \mathrm{~kg} \mathrm{~S}$ $\mathrm{ha}^{-1} \mathrm{~S} ; \mathrm{P} 2=200 \mathrm{~kg} \mathrm{~S} \mathrm{ha-1}$.

\section{pH tanah}

Analisis $\mathrm{pH}$ tanah setelah panen bertujuan untuk mengetahui tingkat kemasaman tanah dalam kaitannya dengan residu $\mathrm{SO}_{4}{ }^{2-}$ dan $\mathrm{S}$ total tanah. Analisis $\mathrm{pH}$ tanah disajikan pada Tabel 7. Kriteria nilai $\mathrm{pH}$ tanah berdasarkan Balai Penelitian Tanah (2009). Berdasarkan hasil analisis $\mathrm{pH}$ tanah setelah panen menunjukkan bahwa $\mathrm{pH}$ tanah dalam kriteria agak masam dan masam. Semakin tinggi dosis pupuk sulfur yang diberikan ke dalam tanah maka dapat menurunkan nilai $\mathrm{pH}$ tanah (Rosmarkan dan Yuwono, 2002). Kemasaman tanah mengalami penurunan dari 6,2 (Tabel 1) menjadi 5,31 dan 5,42 pada perlakuan S1P2 (jumlah siung $1+200$ kg S ha-1) dan S3P2 (jumlah siung $3+200 \mathrm{~kg} \mathrm{~S}$ $\left.\mathrm{ha}^{-1}\right)$. Hal tersebut dapat disebabkan oleh pupuk ZA yang menyebabkan penambahan $\mathrm{H}^{+}$ke dalam tanah. Menurut Sulaeman et al. (2016) pupuk yang mengandung nitrogen dalam bentuk ammonia dapat berubah menjadi nitrat yang berakibat pada penurunan $\mathrm{pH}$ tanah.
Tabel 7. Pengaruh aplikasi pupuk S dan jumlah siung terhadap $\mathrm{pH}$ tanah.

\begin{tabular}{ccc}
\hline Perlakuan & $\mathbf{p H}$ & Kriteria \\
\hline S1P0 & 5,91 & Agak masam \\
S1P1 & 5,50 & Agak masam \\
S1P2 & 5,31 & Masam \\
S2P0 & 5,86 & Agak masam \\
S2P1 & 5,67 & Agak masam \\
S2P2 & 5,57 & Agak masam \\
S3P0 & 5,81 & Agak masam \\
S3P1 & 5,61 & Agak masam \\
S3P2 & 5,42 & Masam \\
\hline
\end{tabular}

Keterangan: $\mathrm{S} 1=$ jumlah siung 1 ; $\mathrm{S} 2=$ jumlah siung 2; S3 = jumlah siung 3; $\mathrm{P} 0=0 \mathrm{~kg} \mathrm{~S} \mathrm{ha-1} \mathrm{S;} \mathrm{P1}=140$ $\mathrm{kg} \mathrm{S} \mathrm{ha-1} \mathrm{S;} \mathrm{P2}=200 \mathrm{~kg} \mathrm{~S} \mathrm{ha}^{-1}$.

Proses nitrifikasi menghasilkan ion-ion hidrogen dan berpotensi meningkatkan kemasaman tanah. Berikut merupakan proses nitrifikasi menurut Havlin et al. (1999):

$2 \mathrm{NH}_{4}{ }^{+}+3 \mathrm{O}_{2} \rightarrow 2 \mathrm{NO}_{2}^{-}+2 \mathrm{H}_{2} \mathrm{O}+4 \mathrm{H}^{+}+\mathrm{e}$ (Nitrosomonas) 


\section{Jurnal Tanah dan Sumberdaya Lahan Vol 8 No 1: 43-50, 2021 \\ e-ISSN:2549-9793, doi: 10.21776/ub.jts1.2021.008.1.6}

Pupuk ZA yang mengandung unsur $\mathrm{N}$ dan $\mathrm{S}$ dapat menurunkan nilai $\mathrm{pH}$ tanah. Hal ini terjadi akibat $\mathrm{SO}_{4}^{2-}$ akan bereaksi dengan molekul air, oksigen dan $\mathrm{CO}_{2}$ di dalam tanah sehingga akan menghasilkan ion sulfat dan ion $\mathrm{H}^{+}$yang dapat menurunkan $\mathrm{pH}$ tanah (Kaya, 2014). Nilai pH tanah setelah panen ini secara tidak langsung dapat berkaitan dengan $\mathrm{S}$ total tanah (Tabel 7). Penggunaan bahan organik dapat meningkatkan $\mathrm{pH}$ tanah dan menurunkan kejenuhan $\mathrm{Al}$ di dalam tanah. Sulaeman et al. (2016) menyatakan bahwa aplikasi pupuk $\mathrm{N}$ ke dalam tanah terutama yang berasal dari ZA dapat memasamkan tanah. Peningkatan dosis pupuk $\mathrm{ZA}$ yang diaplikasikan menurunkan $\mathrm{pH}$ tanah sebagai akibat dari reaksi pupuk ZA dalam tanah dimana setiap satu molekul $\mathrm{NH}_{4}{ }^{+}$menghasilkan $2 \mathrm{H}^{+}$. Reaksi pupuk ZA dalam tanah menurut Havlin et al. (1999) adalah sebagai berikut:

$\left(\mathrm{NH}_{4}\right)_{2} \mathrm{SO}_{4}+4 \mathrm{O}_{2} \rightarrow 4 \mathrm{H}^{+}+\mathrm{SO}_{4^{-}}+2 \mathrm{NO}_{3}^{-}+$ $2 \mathrm{H}_{2} \mathrm{O}$

\section{Kesimpulan}

Aplikasi pupuk sulfur dan jumlah siung tidak berpengaruh nyata terhadap parameter pertumbuhan (tinggi tanaman dan jumlah daun) pada tanaman bawang putih, tetapi berpengaruh nyata meningkatkan diameter umbi, berat umbi segar dan berat umbi kering berturut-turut sebesar $13,39 \%, 140,72 \%$ dan $93,64 \%$ menjadi 24,29 mm, 5.97 g tanaman ${ }^{-1}, 4,57 \mathrm{~g}$ tanaman $^{-1}$ pada perlakuan satu siung umbi dan pupuk $\mathrm{S}$ $140 \mathrm{~kg} \mathrm{ha}^{-1}$ dibanding perlakuan satu siung umbi dan tanpa S. Dilain pihak aplikasi pupuk sulfur dan jumlah siung berpengaruh nyata terhadap residu $\mathrm{SO}_{4}{ }^{2-}$ dan $\mathrm{S}$ total dengan hasil tertinggi berturut-turut 299,3 ppm dan $910 \mathrm{ppm}$, dan hasil terendah diperoleh pada perlakuan tanpa pupuk S.

\section{Ucapan Terima Kasih}

Penulis mengucapkan terima kasih kepada pihak Balai Pengkajian Teknologi Pertanian Jawa Timur yang telah memberikan fasilitas untuk melaksanakan penelitian.

\section{Daftar Pustaka}

Aisyah, A., Suastika, I.W. dan Suntari, R. 2015. Pengaruh aplikasi beberapa pupuk sulfur terhadap residu, serapan, serta produksi tanaman jagung di Mollisol Jonggol, Bogor, Jawa Barat. Jurnal Tanah dan Sumberdaya Lahan 2(1): 93101.

Amagase, H. 2006. Clarifying the real bioactive constituents of garlic. The Journal of Nutrition. 136(3): $716-725$.

Babaleshwar, S.B., Khoppad, S.R., Math, K.K. and Dharmatti, R. 2017. Influence of sulphur on growth and yield of garlic (Allium sativum L.). Journal of Pharmacognosy and Phytochemistry 6(5): 450-452.

Badan Pusat Statistik. 2018. Produksi Tanaman Sayuran: Bawang Putih. Badan Pusat Statistik. https://www.bps.go.id/site/resultTab.Diakses pada tanggal 15 Oktober 2019.

Balai Penelitian Tanah. 2009. Petunjuk Teknis Edisi 2: Analisis Kimia Tanah, Tanaman, Air dan Pupuk. Balai Penelitian Tanah. Bogor. 211-212

Balai Pengkajian Teknologi Pertanian Jawa Timur. 2018. Panduan Budidaya Bawang Putih. http://jatim.litbang.pertanian.go.id/wpcontent/ uploads/2019/04/BAWANG-PUTIH-3.pdf. Diakses pada tanggal 1 Desember 2019

Fatmawati., Y., Susilowati, E. dan Historiawati. 2018. Peningkatan kuantitas bawang merah (Allium cepa fa. Ascalonicum, L) dengan berbagai sumber kalium dan belerang. Jurnal Ilmu Pertanian Tropika dan Subtropika. 3(2): 40-42.

Havlin, J.L., Beaton, J.D., Tisdale, S.L. and Nelson, W.L 1999. Soil Fertility and Fertilizers: An Introduction to Nutrient Management. Sixth Edition. 216-218.

Hore, J.K., Ghanti, S. and Chanchan, M. 2014. Influence of nitrogen and sulphur nutrition on growth and yield of garlic (Allium sativum L.). Journal of Crop and Weed 10(2):14-18.

Jaggi, R.C and Raina, S.K. 2008. Direct, residual and direct + residual effects of sulphur in garlic (Allium sativum) - maize (Zea mays) cropping sequence. Journal of Environmental Biology 29(1) : 85-88.

Karo, B.Br. 2017. Pengaruh pemberian pupuk fosfat dan sulfur terhadap pertumbuhan dan produksi tanaman kentang (Solanum tuberosum) varietas Granola dalam polibag. Jurnal Agroteknosains 1(2): 111-116.

Kaya, E. 2014. Pengaruh pupuk organik dan NPK terhadap $\mathrm{pH}$ dan $\mathrm{K}$-tersedia tanah serta serapan$\mathrm{K}$, pertumbuhan dan hasil padi sawah (Oryza sativa L.). Buana Sains 14(2): 113-122.

Mashtura, S.P., Sufardi and Syukur. 2013. the influence of phosphate and sulfur fertilization on growth and nutrient absorption and rice field yield efficiency of paddy (Oryza sativa L.). Jurnal Manajemen Sumberdaya Lahan. 2(3): 285 - 295. 


\section{Jurnal Tanah dan Sumberdaya Lahan Vol 8 No 1: 43-50, 2021 \\ e-ISSN:2549-9793, doi: 10.21776/ub.jts1.2021.008.1.6}

Prastuti, T.R., Samijan dan Pramono, J. 2011. Intensifikasi Budidaya Bawang Putih. Balai Pengkajian Teknologi Pertanian: Jawa Tengah.

Putra, A.A.G. 2013. Kajian aplikasi dosis pupuk ZA dan kalium pada tanaman bawang putih (Allium sativum L.). Ganec Swara 7(2): 10-17.

Rosmarkan, A. dan Yuwono, N.W. 2002. Ilmu Kesuburan Tanah. Penerbit Kanisius (Anggota Ikapi). 110-113.

Shiferaw, D.G., Dechassa, N., Getachew, K.W. and Sharma, J.J. 2015. Effect of nitrogen, phosphorus, and sulphur fertilizers on growth, yield, and economic returns of garlic (Allium sativum L.). Journal of Wollega University 4(2):1022.

Sufyati, Y., Imran, S.A.K dan Fikrinda. 2006. Pengaruh ukuran fisik dan jumlah umbi per lubang terhadap pertumbuhan dan hasil bawang merah. Jurnal Floratek. (2): 43- 54.
Sulaeman, Y., Maswar dan Erfandi, D. 2016. Pengaruh Kombinasi Pupuk Organik dan Anorganik Terhadap Sifat Kimia Tanah dan Hasil Tanaman Jagung di Lahan Kering Masam. Balai Penelitian Tanah. 1-7

Sunaryo, Y., Purnomo, D., Darini, and Cahyani, V.R. 2018. Nutrients content and quality of liquid fertilizer made from goat manure. Journal of Physics: Conference Series 1022 (1), 012053.

Zaman, M.S., Hashiem, A.M., Jahiruddin, M. and Rahim, M.A. 2011. Effect of sulphur fertilization on the growth and yield of garlic (Allium sativum L.). Bangladesh Journal of Agriculture Research 36(4): 647-656. 